\title{
Alat Uji Kualitas Madu Menggunakan Polarimeter Dan Sensor Warna
}

\author{
Bagus Arief Wibowo, Muhammad Rivai, dan Tasripan \\ Teknik Elektro, Fakultas Teknologi Industri, Institut Teknologi Sepuluh Nopember (ITS) \\ Jl. Arief Rahman Hakim, Surabaya 60111 Indonesia \\ e-mail:muhammad_rivai@ee.its.ac.id
}

\begin{abstract}
Abstrak - Madu merupakan cairan kental menyerupai sirup yang memiliki rasa manis. Rasa manis dalam madu terbentuk secara alami oleh lebah dan serangga yang berasal dari nektar bunga. Kandungan madu didominasi oleh gula $(\mathbf{7 9 , 8 \% )}$ dan air (17\%). Di lapangan banyak terjadi kasus pemalsuan madu yang mengakibatkan hilangnya sifat manis alami dari madu tersebut. Untuk mengetahui pemalsuan tersebut biasanya dilakukan uji laboratorium yang dirasa kurang efisien. Dalam penelitian ini dilakukan pembuatan alat uji kualitas madu dengan menggunakan polarimeter dan sensor warna untuk mengetahui madu alami atau campuran. Madu mengandung gula yang dapat memutar bidang polarisasi sehingga ketika konsentrasi gula semakin tinggi, maka semakin jauh pula simpangan sudutnya. Rotasi optis yang diamati/diukur bergantung kepada jumlah senyawa dalam tabung madu, panjang jalan/larutan yang dilalui cahaya, temperatur pengukuran, dan panjang gelombang cahaya yang digunakan. Sensor warna berfungsi untuk mengambil data RGB dari 2 jenis madu yang diuji pada alat ini yaitu madu karet dan madu kapas. Berdasarkan pengujian didapatkan bahwa untuk madu karet alami menghasilkan

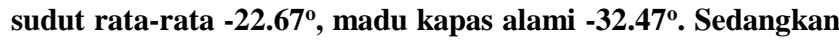
untuk madu karet campuran (madu karet 35 ml+larutan glukosa $10 \% 35 \mathrm{ml}$ ) menghasilkan sudut rata-rata $-4.55^{\circ}$, dan madu kapas campuran (madu kapas $35 \mathrm{ml}+$ larutan glukosa $10 \% 35 \mathrm{ml}$ ) dengan sudut rata-rata $-17.66^{\circ}$. Sedangkan kemungkinan keberhasilan pendeteksian kualitas untuk madu karet alami sebesar $\mathbf{4 0 \%}$, madu kapas alami $80 \%$, madu karet campuran $100 \%$, dan madu kapas campuran $100 \%$
\end{abstract}

Kata Kunci-Polarimeter, Sensor Warna, Madu, Glukosa,fruktosa

\section{PENDAHULUAN}

$\mathrm{M}$ ADU merupakan cairan kental menyerupai syrup dengan rasa manis seperti larutan gula. Rasa manis dalam madu terbentuk secara alami oleh lebah dan serangga yang berasal dari nektar bunga. Dari 100 gram madu terdapat sekitar 82 gram merupakan karbohidrat dan 17 gram merupakan air [1]. Untuk memperoleh madu yang alami dibutuhkan biaya yang lumayan besar dikarenakan prosesnya yang cukup lama. Oleh karena itu dilihat dari komposisi madu yang sebagian besar merupakan karbohidrat, maka banyak dari produsen yang dengan sengaja mencampurkan syirup glukosa dan fruktosa untuk mencampur madu yang sebenarnya belum layak untuk dipanen. Hal ini dilakukan agar produsen memperoleh keuntungan yang sebesar-besarnya dengan modal yang kecil [2]. Untuk dapat mengetahui keaslian dari madu tersebut perlu adanya uji laboratorium. Namun hal ini menjadi kurang efektif apabila menginginkan diperolehnya data secara langsung dan cepat.

Dengan menggunakan alat ukur polarimeter dapat diketahui kadar gula yang terdapat pada madu. Pada saat konsentrasi gula semakin tinggi, maka cahaya yang tertahan di analisator menjadi lebih redup. Sehingga sudut putar jenisnya pun menjadi semakin besar. Ini menandakan larutan gula dapat membelokan arah getar cahaya. Rotasi optis yang diamati/diukur bergantung kepada jumlah senyawa dalam tabung madu, panjang jalan/larutan yang dilalui cahaya, temperatur pengukuran, dan panjang gelombang cahaya yang digunakan. Dengan tambahan sensor warna dapat diketahui jenis madu tersebut [3]. Modul sensor warna yang digunakan adalah DT Sense Color Sensor menggunakan chip TAOS TCS3200. Modul ini telah terintegrasi dengan 2 LED. Sensor Warna TCS3200 mendeteksi dan mengukur intensitas warna tampak pada madu. Chip TCS3200 memiliki beberapa fotodioda, dengan masing-masing filter warna yaitu, merah, hijau, biru, dan clear. Filter-filter tersebut didistribusikan pada masing-masing array. Modul ini memiliki osilator yang menghasilkan pulsa kotak yang frekuensinya sebanding dengan perubahan warna yang dideteksi [4].

Dua parameter di atas diharapkan dapat menjadi acuan apakah madu tersebut alami atau campuran. Sehingga dalam penelitian ini telah dibuat sebuah alat uji kualitas madu menggunakan polarimeter dan sensor warna yang dapat mengatasi masalah tersebut. Diharapkan konsumen tidak akan ragu lagi tentang kealamian madu yang dikonsumsinya.

\section{TEORI PENUNJANG}

\section{A. Cairan Madu}

Madu adalah nektar atau eksudat gula dari tanaman yang dikumpulkan oleh lebah madu, diolah dan disimpan dalam sarang lebah Apis Mellifera [5]. Nektar bunga yang telah dihisap diolah dalam tubuh lebah dengan dicampur enzim tertentu. Ketika lebah kembali ke sarang, campuran dan bahan kimia tadi disimpan dalam sel dan setelah masak campuran tadi berubah menjadi madu. Mereka umumnya tertarik dengan bunga warna kuning dan biru

Komposisi madu dipengaruhi dua hal, yaitu komposisi nektar yang dihasilkan dan berhasil dikumpulkan oleh lebah serta faktor eksternal seperti cuaca dan iklim [6]. Selain itu banyak tidaknya bunga, derajat kematangan madu serta cara ekstraksinya juga turut mempengaruhi komposisinya. Kadar yang paling menonjol adalah fruktosa dan glukosa, kadar keduanya mencapai 85 - $95 \%$ dari total 
karbohidrat pada madu. Selain karbohidrat, madu juga mengandung mineral seperti fosfor, kalium, natrium $\mathrm{Fe}$, kalsium, dan berbagai trace mineral seperti sulfur, magnesium, mangan, silika dan tembaga. Adanya mineralmineral ini dinyatakan dalam total kadar abu. Madu asli harus bersifat memutar bidang polarisasi ke kiri (levoratory), berarti untuk madu asli kadar fruktosanya harus lebih besar daripada kadar glukosanya. Zat penting lainnya pada madu adalah vitamin terutama tiamin, riboflavin, biotin, asam askorbat, piridoksin, niacin, asam pantotenat, dan macam-macam enzim seperti amilase, glukosa oksidase, katalase, invertase, diastase, peroksidase, pospatase asam dan enzim-enzim proteolitik. Semua enzim ini berasal dari nektar, serbuk sari, dan sekresi kelenjar saliva lebah [6].

\section{B. Konsep Dasar Polarimeter}

Polarimeter adalah perangkat untuk analisa yang didasari oleh pengukuran sudut putaran sinar monokromatis karena cahaya itu terpolarisasi linier oleh bahan bening yang bersifat optis aktif. Sinar monokromatis tersebut mempunyai sejumlah bidang getar yang banyak sekali. Adapun yang dimaksud cahaya terpolarisasi adalah cahaya yang mempunyai satu arah getar dan arah getar itu berada tegaklurus terhadap arah rambatnya. Bahan optis aktif merupakan bahan yang bila dijatuhi cahaya maka bidang polarisasi dapat terputar. Zat yang memiliki sifat optis aktif ditandai dengan adanya kandungan atom karbon simetris atau susunan atom $\mathrm{C}$ berupa kristal dan berada di dalam senyawa organik. Contoh bahan optis aktif yang biasanya digunakan dalam eksperimen adalah larutan gula, dan terjadi pada beragam variasi konsentrasi.

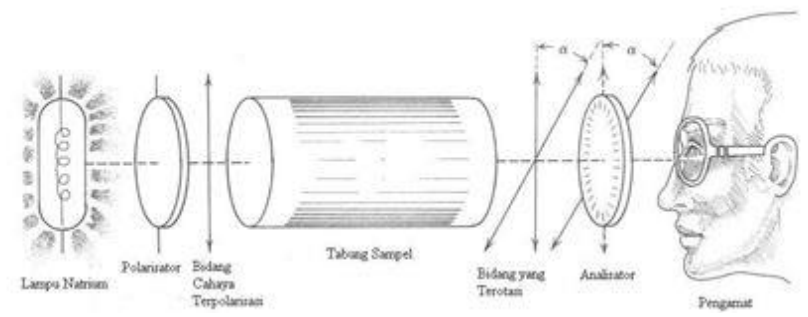

Gambar 1. Skema dari alat polarimeter

Cahaya dari lampu sumber, terpolarisasi setelah melewati prisma Nicol pertama yang disebut polarisator. Cahaya terpolarisasi kemudian melewati senyawa optis aktif yang akan memutar bidang cahaya terpolarisasi dengan arah tertentu. Prisma Nicol kedua yang disebut analisator akan membuat cahaya dapat melalui celah secara maksimum. Kemudian pengamat akan menerima cahaya setelah melalui analisator seperti terlihat pada gambar 1 [7].

$$
[\alpha]_{\lambda}^{\mathrm{t}}=\frac{\alpha}{c l}
$$

$\alpha \quad=$ rotasi optik (yang teramati)

c $\quad=$ konsentrasi larutan gram $/ \mathrm{mL}$ larutan

I = panjang jalan/larutan yang dilalui cahaya dalam desimeter

$\lambda=$ panjang gelombang cahaya (bila menggunakan lampu natrium dilambangkan dengan " $\mathrm{D}$ “)

$\mathrm{t}=$ temperatur $\left({ }^{\circ} \mathrm{C}\right)$.

Rotasi optis yang diamati/diukur dari suatu larutan bergantung kepada jumlah senyawa dalam tabung sampel, panjang jalan/larutan yang dilalui cahaya, temperatur pengukuran, dan panjang gelombang cahaya yang digunakan. Untuk mengukur rotasi optik, diperlukan suatu besaran yang disebut rotasi spesifik yang diartikan suatu rotasi optik yang terjadi bila cahaya terpolarisasi melewati larutan dengan konsentrasi 1 gram per mililiter sepanjang 1 desimeter. Rotasi spesifik dapat dihitung dengan

Rotasi optik yang termati dapat berupa rotasi yang searah jarum jam, rotasi ini disebut putar kanan dan diberi tanda (+), sedangkan senyawa yang diukurnya disebut senyawa dekstro (d). Rotasi yang berlawanan dengan arah jarum jam disebut putar kiri dan diberi tanda (-), senyawanya disebut senyawa levo (1). Madu mengandung fruktosa yang bersifat levo dan glukosa yang bersifat dekstro sehingga dengan menggunakan konsep polarimeter ini, rotasi optik dari sampel madu dapat terbaca

\section{DT-SENSE COLOR SENSOR}

Modul Sensor Warna TCS3200 seperti ditunjukkan pada gambar 2 menggunakan chip TAOS TCS3200 RGB. Modul ini telah terintegrasi dengan 2 LED. masing-masing filter warna yaitu, merah, hijau, biru, dan clear. Filter-filter tersebut didistribusikan pada masing-masing array. Modul ini memiliki osilator yang menghasilkan pulsa square yang frekuensinya sebanding dengan warna yang dideteksi [4].

TCS3200 merupakan konverter cahaya ke frekuensi yang dapat diprogram yang menggabungkan konfigurasi fotodioda silikon dan konverter arus ke frekuensi pada IC CMOS Single Monolithic. Output berupa gelombang persegi (duty cycle 50\%) dengan frekuensi yang berbanding lurus dengan intensitas cahaya.
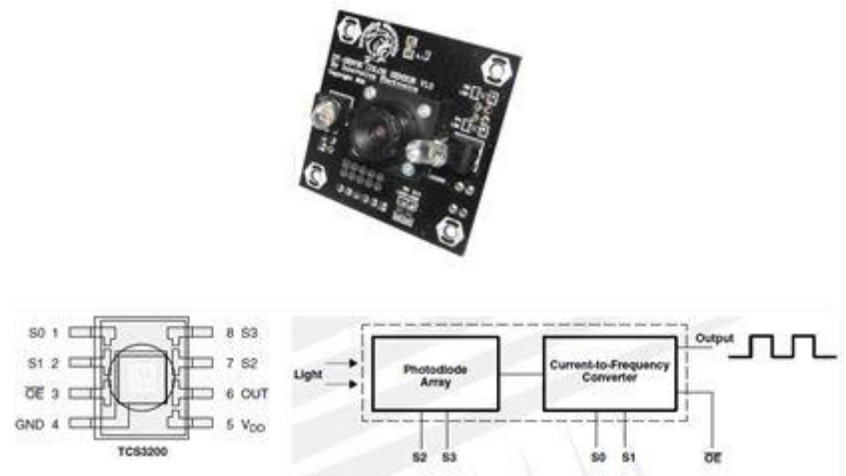

Gambar 2. DT Sense Color Sensor dan Diagram Blok IC TCS3200

Output frekuensi skala penuh dapat ditingkatkan oleh salah satu dari tiga nilai yang telah ditetapkan melalui dua pin input kontrol. Input digital dan output digital memungkinkan antarmuka langsung ke mikrokontroler atau rangkaian logika lainnya. Output Enable (OE) menempatkan output dalam keadaan impedansi tinggi untuk beberapa masukan pada mikrokontroler. Dalam TCS3200, konverter cahaya ke frekuensi membaca $8 \times 8$ deret fotododioda. Terdiri dari 16 fotodioda filter biru, 16 fotodioda filter hijau, 16 fotodioda filter merah, dan 16 fotodioda adalah clear tanpa filter. Keempat fotodioda tersebut digunakan untuk memnimalkan efek keseragaman pancaran cahaya. 


\section{Teori Dasar Gearbox}

Jika dua gir dengan diameter berbeda ditautkan, mereka akan berputar dengan kecepatan yang berbeda pula. Arah putarnya menjadi berlawanan antara satu gir dengan gir lainnya, untuk mendapatkan arah putaran yang sama seperti pada poros utama (biasanya yang terdapat pada motor), maka gir harus disusun dengan jumlah ganjil. Secara teori ukuran roda gir digambarkan dengan lingkaran (pitch circle) memiliki diameter (pitch diameter) yang lebih kecil dari diameter keseluruhan gir karena gigi gir saling berpotongan (overlap). Jarak antara gigi satu dan yang lain dalam satu gir disebut dengan circular pitch. Jumlah gigi pada suatu gir dapat ditentukan dengan rumus:

$$
N=\frac{\text { Keliling Gear }}{\text { Jarak Antar Gigi }}=\frac{\pi D}{P_{C}}
$$

Dimana : $\mathrm{N}=$ jumlah gigi, $\mathrm{D}=$ pitch diameter

$\mathrm{P}_{\mathrm{C}}=$ circular pitch (jarak antar gigi)

\section{E. Mikrokontroler ATmegal6}

Pada saat ini mikrokontroler sudah sangat dikenal dikalangan masyarakat umum. karena alat ini biasa terdapat dalam berbagai peralatan seperti telepon digital, microwave oven, televise, mesin cuci, sistem keamanan rumah, PDA, dan lain sebagainya. Salah satu mikrokontroller yang banyak dipakai adalah AVR ATmega16. Mikrokontroler ini didesain dalam bentuk DIP (Dual Inline Package) 40 pin. Gambar 3 merupakan konfigurasi ATmega16 [8].

\begin{tabular}{|c|c|c|c|}
\hline (/TO) PBO & 1 & 40 & PAO $(A D C 0)$ \\
\hline (T1) PB1 G & 2 & so日 & PA1 (ADC1) \\
\hline (INI 2SAINO) PB2 C & 3 & $3 s$ - & $\mathrm{PA} 2(\mathrm{ADC} 2)$ \\
\hline (OCOAAIN1) PB3 C & 4 & 37 . & PA3 (ADC3) \\
\hline (SS) PB4 & 5 & 36 - & PAA (ADCA) \\
\hline (MOSI) PBS D & 8 & 36 日 & PA5 (ADC5) \\
\hline (Miso) PB6 С & 7 & $34 \mathrm{~B}-2 \mathrm{n}$ & PA6 (ADC6) \\
\hline (SCK) PB7 & B & 33 . & PAC (ADCT) \\
\hline RESET C & 9 & 32 D -1 & AREF \\
\hline voc Z & 10 & 315 & GND \\
\hline GND ב & 11 & $30 \mathrm{~B}$ & AVCC \\
\hline XTAL.2 C & 12 & 20 & PC7 ( $\operatorname{coscz}$ \\
\hline XTALI A & 13 & 28 & PC6 (TOSC1) \\
\hline (RXD) PDO ב & 14 & $27=$ & PCS (TDI) \\
\hline (TXD) PDI D & 15 & $28 \mathrm{~B}-(-2$ & $P C A(T D O)$ \\
\hline (INTO) PD2 С & 18 & 25 & PC3 (TMS) \\
\hline (INT1) PD3 C & 17 & $24 E$ & $P C 2$ (ICK) \\
\hline (OC18) PD4 듬 & 18 & 23 & PC1 (SDA) \\
\hline (OC1A) PD6 ב & 18 & 22 & $P C O$ (SCL) \\
\hline (ICP1) PD6 믐 & 20 & 21 & $\mathrm{PD} 7(\mathrm{OCZ})$ \\
\hline
\end{tabular}

Gambar 3. Konfigurasi kaki (pin) ATmega16

\section{PERANCANGAN SISTEM}

Sistem yang dirancang terdiri dari dua bagian utama, yaitu sistem akuisisi data dan sistem pemrosesan data seperti ditunjukkan pada gambar 4. Pada bagian sistem akuisisi data terdapat sensor cahaya (LDR), analisator, sampel, polarisator dan sumber cahaya (dioda laser), sedangkan pada bagian sistem pemrosesan data terdapat ATMega 16 dan LCD 2x16 sebagai tampilan informasi yang dibutuhkan untuk pengguna. Pada bagian sistem akusisi data, sensor cahaya berfungsi sebagai pengambil cahaya dari dioda laser yang dilewatkan pada kuvet (tabung bahan uji). Selanjutnya analisator akan berputar untuk mendapatkan nilai tergelap dari cahaya yang dilewatkan pada kuvet.

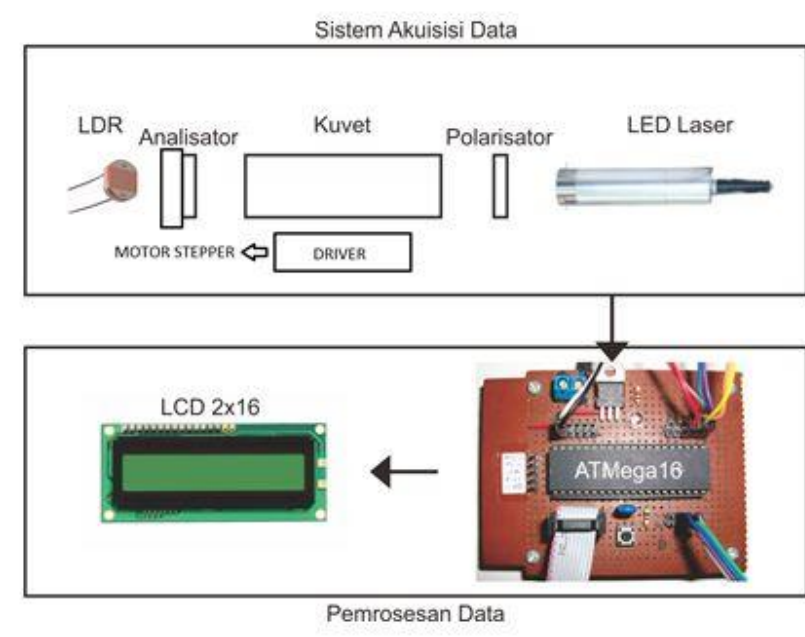

Gambar 4. Ilustrasi Cara Kerja Sistem

Sistem yang dirancang ini memiliki fungsi untuk mendapatkan nilai sudut simpangan yang diperoleh dari perputaran analisator. Simpangan sudut ini merupakan parameter yang digunakan untuk menghitung berapa besar kadar gula dalam madu. Secara keseluruhan, cara kerja alat seprti pada gambar 5 sebagai berikut :

1. Sumber cahaya memancarkan cahaya dengan nilai panjang gelombang tertentu.

2. Polarisator digunakan untuk memfilter sumber cahaya tidak terpolarisasi menjadi cahaya terpolarisasi.

3. Kuvet yang digunakan sebagai wadah sampel akan menerima pancaran cahaya dan akan diteruskan menuju analisator.

4. Analisator akan berputar dengan bantuan motor stepper yang bergerak berdasarkan sensor cahaya (LDR) .

5. Sensor cahaya (LDR) menangkap cahaya.

6. Sensor warna akan mendeteksi warna bahan uji

7. ATMega 16 kemudian akan memproses data dari kedua sensor untuk kemudian ditampilkan pada LCD 2x16

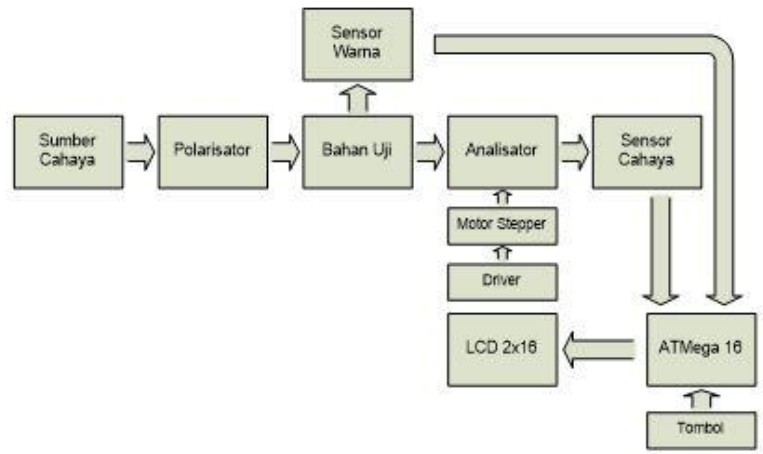

Gambar 5. Blok Diagram Sistem secara Keseluruhan

\section{A. Perancangan Perangkat Keras}

Perangkat keras yang digunakan dalam sistem ini merupakan perangkat dasar yang digunakan untuk membangun sebuah Polarimeter. Perangkat keras yang digunakan diantaranya adalah sumber cahaya berupa dioda laser, kuvet sebagai wadah sampel madu, polarisator dan analisator, sensor warna, sensor cahaya serta ATMega 16 untuk proses komputasi dan program. 


\section{B. Perancangan Perangkat Lunak}

Pada bagian perancangan perangkat lunak ini seperti yang ditunjukkan pada gambar 6 meliputi algoritma pemrograman yang digunakan yaitu pengambilan data, pengolahan data dan interpretasi data.

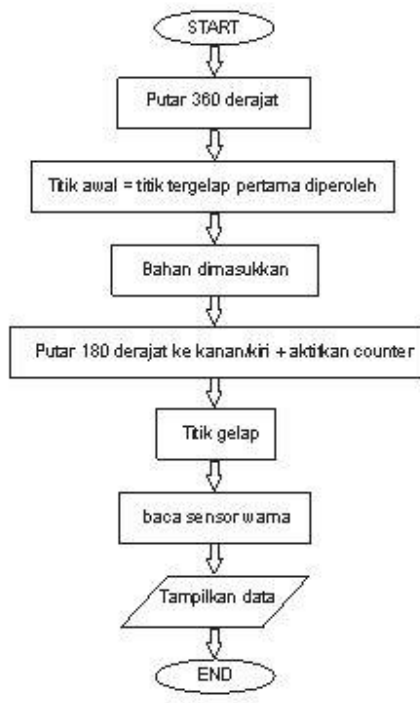

Gambar 6. Flow Chart

\section{Hasil Akhir Desain Perancangan Sistem}

Hasil akhir dari desain perancangan yang ditunjukkan pada gambar 7 berupa sebuah sistem polarimeter dengan tambahan modul sensor warna yang dapat membedakan madu alami dengan madu campuran

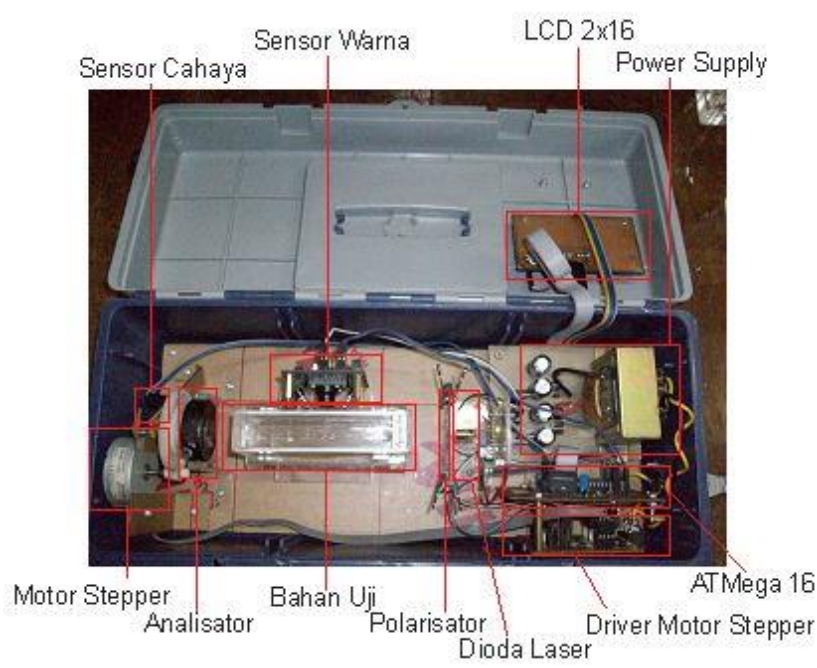

Gambar 7. Sistem Polarimeter dan sensor warna

\section{HASIL PENGUJIAN}

Pada bab ini akan dilakukan pengujian bahan yaitu berupa larutan fruktosa standar, larutan glukosa standar, sampel madu alami dan sampel madu campuran.

\subsection{Pengujian larutan fruktosa standar}

Pada pengujian ini yang ditunjukkan pada tabel 1, rancangan sistem polarimeter akan diuji untuk mengukur rotasi optik larutan fruktosa dari masing-masing konsentrasi. Larutan fruktosa ini dibuat dari larutan induk fruktosa yang ada dipasaran dengan kadar konsentrasi
5.5\%. Menurut sifat putar optiknya, larutan fruktosa bersifat levo rotary yaitu akan memutar bidang polarisasi ke kiri atau negatif. Setelah dilakukan pengujian, sistem polarimeter mampu membaca larutan fruktosa standar dimana larutan ini memutar bidang polarisasi kearah kiri atau negatif . Garfik pengujian ditunjukkan pada gambar 8.

\begin{tabular}{|c|c|c|c|c|}
\hline \multirow{2}{*}{ Kadar } & \multicolumn{3}{|c|}{ Rotasi Optik $\left(^{\circ}\right)$} & \multirow{2}{*}{ Rata-rata } \\
\hline & Perc. 1 & Perc. 2 & Perc. 3 & \\
\hline $1 \%$ & -1.88 & -1.88 & -1.88 & -1.88 \\
\hline $2 \%$ & -7.51 & -6.26 & -6.26 & -6.68 \\
\hline $3 \%$ & -9.39 & -10.02 & -10.64 & -10.02 \\
\hline $4 \%$ & -13.15 & -14.4 & -13.15 & -13.57 \\
\hline $5.50 \%$ & -24.41 & -24.41 & -25.04 & -24.62 \\
\hline
\end{tabular}

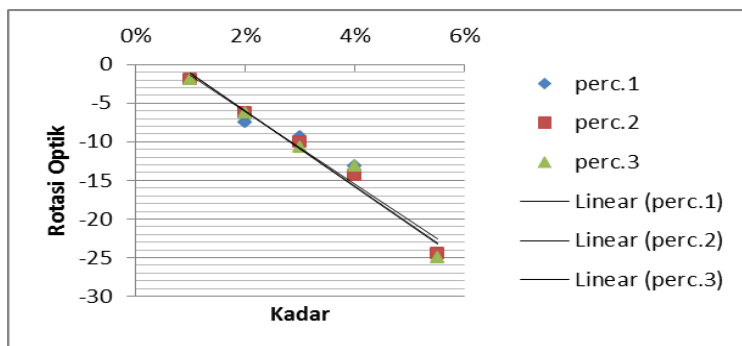

Gambar 8 Grafik Hasil Percobaan Fruktosa

4.2 Pengujian larutan Glukosa standar

Pada pengujian ini, rancangan sistem polarimeter akan diuji untuk mengukur rotasi optic larutan glukosa standar dari masing-masing konsentrasi. Larutan glukosa ini dibuat dari larutan induk glukosa yang ada dipasaran dengan kadar konsentrasi $85 \%$. Menurut sifat putar optiknya, larutan glukosa bersifat dextro rotary yaitu akan memutar bidang polarisasi ke kanan atau positif. Setelah dilakukan pengujian seperti pada tabel 2, sistem polarimeter mampu membaca larutan glukosa standar dimana larutan ini memutar bidang polarisasi kearah kanan atau positif. Grafik pengujian ditunjukkan pada gambar 9 .

Tabel 2
\begin{tabular}{|r|r|r|r|r|}
\hline \multirow{2}{*}{ Kadar } & \multicolumn{3}{|c|}{ Hotasi Optik $\left({ }^{\circ}\right)$} & \multirow{2}{*}{ Rata-rata } \\
\cline { 2 - 5 } & \multicolumn{1}{|c|}{ Perc.1 } & Perc. 2 & \multicolumn{1}{c|}{ Perc. 3} & \\
\hline $10 \%$ & 13.48 & 14.11 & 13.48 & 13.69 \\
\hline $20 \%$ & 27.26 & 27.88 & 29.13 & 28.09 \\
\hline $30 \%$ & 41.65 & 45.41 & 42.28 & 43.11 \\
\hline $40 \%$ & 62.31 & 61.69 & 62.31 & 62.10 \\
\hline $50 \%$ & 77.96 & 81.09 & 79.84 & 79.63 \\
\hline
\end{tabular}

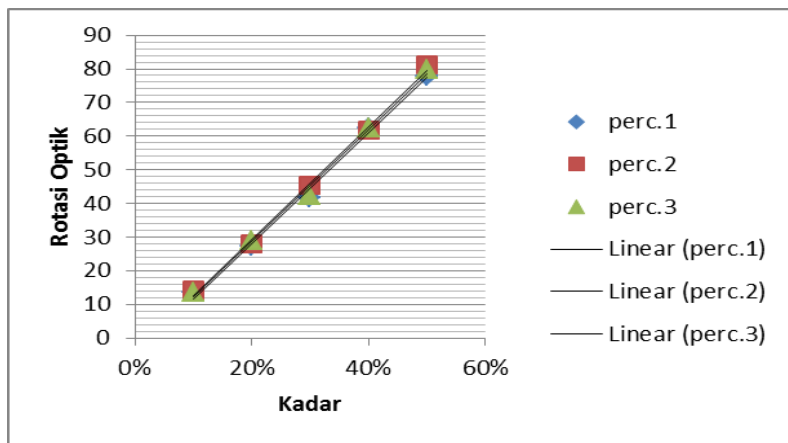


Gambar 9 Grafik Hasil Percobaan Glukosa

\subsection{Pengujian sampel madu karet alami}

Pada pengujian ini, rancangan sistem polarimeter dan sensor warna akan diuji untuk mengukur rotasi optik dan nilai warna dari sampel madu karet alami. Dari pengujian yang ditunjukkan pada tabel 3, didapatkan madu karet alami menghasilkan sudut rata-rata $-22.67^{\circ}$

Tabel 3 Hasil Pengujian Alat pada madu karet alami

\begin{tabular}{|l|r|r|r|r|}
\hline & \multirow{2}{*}{$\begin{array}{c}\text { Rotasi } \\
\text { Optik }\left(^{\circ}\right)\end{array}$} & \multicolumn{3}{|c|}{ Warna } \\
\cline { 3 - 5 } & & \multicolumn{1}{c|}{ Red } & \multicolumn{1}{c|}{ Green } & \multicolumn{1}{c|}{ Blue } \\
\hline Perc. 1 & -22.87 & 63 & 41 & 34 \\
\hline Perc. 2 & -22.87 & 69 & 41 & 28 \\
\hline Perc. 3 & -22.25 & 63 & 41 & 28 \\
\hline Rata-rata & -22.67 & 65 & 41 & 30 \\
\hline
\end{tabular}

\subsection{Pengujian sampel madu kapas alami}

Pada pengujian ini, rancangan sistem polarimeter dan sensor warna akan diuji untuk mengukur rotasi optik dan nilai warna dari sampel madu kapas alami. Dari pengujian yang ditunjukkan pada tabel 4 , didapatkan madu kapas alami menghasilkan sudut rata-rata $-32.47^{\circ}$

Tabel 4 Hasil pengujian alat pada madu kapas alami

\begin{tabular}{|l|r|r|r|r|}
\hline & \multirow{2}{*}{\begin{tabular}{c} 
Rotasi \\
\cline { 3 - 5 }
\end{tabular}} & & \multicolumn{3}{|c|}{ Optik $\left(^{\circ}\right)$} & \multicolumn{1}{c|}{ Red } & \multicolumn{1}{c|}{ Green } & \multicolumn{1}{c|}{ Blue } \\
\hline Perc. 1 & -35.39 & 81 & 47 & 34 \\
\hline Perc. 2 & -30.39 & 86 & 47 & 34 \\
\hline Perc. 3 & -31.64 & 86 & 47 & 34 \\
\hline Rata-rata & -32.47 & 84.33 & 47 & 34 \\
\hline
\end{tabular}

4.5 Pengujian sampel madu karet campuran dan madu kapas campuran

Pada pengujian ini, rancangan sistem polarimeter dan sensor warna akan diuji untuk mengukur rotasi optik dan nilai warna dari sampel madu karet campuran dan madu kapas campuran. Dari hasil pengujian diperoleh data bahwa sampel madu karet campuan (dengan komposisi madu karet $35 \mathrm{ml}$ larutan glukosa $10 \% 35 \mathrm{ml}$ ) menghasilkan sudut rata-rata $-4.55^{\circ}$, dan madu kapas campuran (dengan komposisi madu kapas $35 \mathrm{ml}+$ larutan glukosa $10 \% 35 \mathrm{ml}$ ) dengan sudut rata-rata $-17.66^{\circ}$.

\begin{tabular}{|c|c|c|c|c|}
\hline \multirow[t]{3}{*}{ Tabel 5} & \multicolumn{4}{|c|}{ Pengujian pada madu karet campuran } \\
\hline & \multirow{2}{*}{$\begin{array}{c}\text { Rotasi } \\
\text { Optik }\left({ }^{\circ}\right)\end{array}$} & \multicolumn{3}{|c|}{ Warna } \\
\hline & & Red & Green & Blue \\
\hline Perc. 1 & -11.16 & 81 & 59 & 46 \\
\hline Perc. 2 & 1.25 & 81 & 59 & 57 \\
\hline Perc. 3 & 1.25 & 81 & 57 & 46 \\
\hline Rata-rata & -4.55 & 81 & 28.33 & 49.67 \\
\hline
\end{tabular}

Tabel 6 Pengujian pada madu kapas campuran

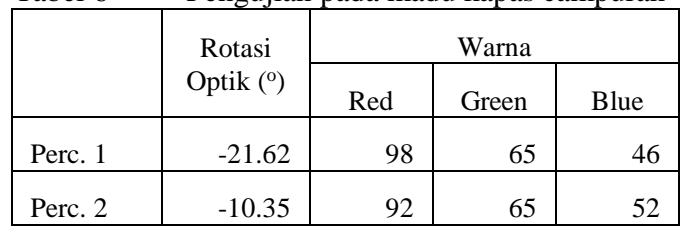

\begin{tabular}{|l|r|r|r|r|} 
Perc. 3 & -21 & 98 & 59 & 46 \\
\hline Rata-rata & -17.66 & 96 & 63 & 48 \\
\hline
\end{tabular}

Dari hasil percobaan yang ditunjukkan pada tabel 5 dan tabel 6 di atas dapat dilihat bahwa ketika madu mengalami campuran, baik itu madu karet alami atau madu kapas alami, rotasi optiknya juga akan berubah.ini dikarenakan larutan glukosa memutar bidang polarisasi ke kanan atau positif.

\subsection{Pengujian Kualitas Madu}

Seluruh sampel madu yang berjumlah 4 jenis akan diuji menggunakan rancangan sistem polarimeter dan sensor warna untuk mengetahui apakah alat mampu membedakan madu alami dengan madu campuran. Prosedur yang harus dilakukan adalah dengan dengan terlebih dahulu mengkaliberasi alat supaya berada pada titik nol (tergelap). Kemudian dilakukan pengujian sampel madu. Setelah pengujian pertama selesai, selanjutnya dilakukan pengkaliberasian ulang dengan tujuan agar hasil permbacaan alat presisi. Begitu seterusnya untuk sampel madu selanjutnya.

Tabel 7 Pengujian Kualitas Madu

\begin{tabular}{|c|c|c|c|c|c|c|}
\hline \multirow{2}{*}{$\begin{array}{c}\text { Jenis } \\
\text { Sampel }\end{array}$} & \multirow{2}{*}{ Perc. } & \multirow{2}{*}{$\begin{array}{l}\text { Rotasi } \\
\text { Optik } \\
\left(^{\circ}\right)\end{array}$} & \multicolumn{3}{|c|}{ Nilai Warna } & \multirow{2}{*}{ Hasil } \\
\hline & & & $\mathrm{R}$ & G & B & \\
\hline \multirow{5}{*}{$\begin{array}{l}\text { Madu } \\
\text { Karet } \\
\text { Alami }\end{array}$} & 1 & -22.25 & 69 & 35 & 34 & madu campuran \\
\hline & 2 & -22.87 & 63 & 41 & 34 & madu karet alami \\
\hline & 3 & -27.88 & 69 & 35 & 34 & madu campuran \\
\hline & 4 & -24.75 & 63 & 41 & 28 & madu karet alami \\
\hline & 5 & -28.51 & 63 & 41 & 28 & madu campuran \\
\hline \multirow{5}{*}{$\begin{array}{l}\text { Madu } \\
\text { Kapas } \\
\text { Alami }\end{array}$} & 1 & -29.13 & 86 & 47 & 34 & madu kapas alami \\
\hline & 2 & -31.64 & 86 & 47 & 34 & madu kapas alami \\
\hline & 3 & -28.51 & 81 & 47 & 34 & madu kapas alami \\
\hline & 4 & -35.39 & 86 & 47 & 34 & Madu campuran \\
\hline & 5 & -30.39 & 81 & 53 & 34 & madu kapas alami \\
\hline \multirow{5}{*}{$\begin{array}{c}\text { Madu } \\
\text { Karet } \\
\text { Campuran }\end{array}$} & 1 & 1.25 & 81 & 59 & 57 & madu campuran \\
\hline & 2 & $\underline{0}$ & 81 & 59 & 57 & madu campuran \\
\hline & 3 & 1.25 & 81 & 59 & 57 & madu campuran \\
\hline & 4 & -11.16 & 81 & 59 & 57 & madu campuran \\
\hline & 5 & -11.61 & 81 & 59 & 57 & madu campuran \\
\hline \multirow{5}{*}{$\begin{array}{c}\text { Madu } \\
\text { Kapas } \\
\text { Campuran }\end{array}$} & 1 & -10.35 & 92 & 65 & 52 & madu campuran \\
\hline & 2 & -21.62 & 92 & 65 & 52 & madu campuran \\
\hline & 3 & -22.25 & 92 & 65 & 52 & madu campuran \\
\hline & 4 & -21 & 92 & 65 & 52 & madu campuran \\
\hline & 5 & -12.23 & 92 & 65 & 52 & madu campuran \\
\hline
\end{tabular}

Berdasarkan data pada tabel 7 diperoleh kemungkinan keberhasilan untuk pengujian madu karet alami sebesar $40 \%$, madu kapas alami $80 \%$, madu karet campuran $100 \%$, dan madu kapas campuran $100 \%$ 


\section{KESIMPULAN}

Kualitas madu bisa ditentukan dari kandungan gula yang terdapat di dalamnya. Komposisi gula yang terdapat di dalam madu didominasi oleh fruktosa yang bersifat memutar bidang polarisasi kekiri dan glukosa yang bersifat memutar bidang polarisasi kekanan sehingga dengan menggunakan polarimeter akan diperoleh sudut putar dari masing masing madu. Selain dari kandungan gula, secara umum kualitas madu juga bisa dilihat dari warnanya. Walaupun warna tidak secara langsung bisa menentukan kualitas madu karena warna madu bergantung dari jenis nektar bunga. Berdasarkan pengujian yang telah dilakukan diperoleh bahwa untuk madu karet alami menghasilkan sudut rata-rata $-22.67^{\circ}$, madu kapas alami $-32.47^{\circ}$. Sedangkan untuk madu karet campuran (komposisi : madu karet 35 ml+larutan glukosa $10 \% 35 \mathrm{ml}$ ) menghasilkan sudut rata-rata $-4.55^{\circ}$, dan madu kapas campuran (komposisi : madu kapas $35 \mathrm{ml}+$ larutan glukosa 10\% 35 ml) dengan sudut rata-rata $-17.66^{\circ}$. Nilai sudut madu campuran lebih besar dibandingkan dengan nilai sudut madu alami karena larutan glukosa memiliki sifat memutar bidang polarisasi ke kanan sehingga dapat dibedakan antara madu alami dengan madu campuran. Sedangkan kemungkinan keberhasilan pendeteksian untuk madu karet alami sebesar $40 \%$, madu kapas alami $80 \%$, madu karet campuran $100 \%$, dan madu kapas campuran $100 \%$

\section{DAFTAR PUSTAKA}

[1] http://nutritiondata.self.com/facts/sweets/5568/2

[2] V. Morales , N. Corzo , M.L. Sanz , "HPAEC-PAD oligosaccharide analysis to detect adulterations of honey with sugar syrups," 2008 Food Chemistry 107, pp. 922-928, 2008

[3] Pia Valeria Aloisi1, "Determination Of Quality Chemical Parameters Of Honey From Chubut (Argentinean Patagonia)," Chilean Journal Of Agricultural Research 70(4), Pp. 640-645, October-December 2010

[4] Datasheet, "DT-Sense Color Sensor", Innovative Electronics, 2010

[5] Winarno, F.G. 1981.: Madu,Teknologi, Khasiat dan Analisa. Pusbangtepa, Bogor, Hal. 25-26; 29-37; 51-55.

[6] White, Jonathan W., 1977. Specific Determination of Sucrose in Honey. JAOAC, 60 (3): 669 - 670.

[7] Pratiwi N.D., Oktaviani S. N. A., Agustihana S., "Polarimeter", Jurna Eksperimen Gelombang Optik, Vol. 01, No. 01, 2012

[8] Andrianto Heri., Pemograman Mikrokontroller AVR Atmega16 Menggunakan Bahasa C(CodeVision AVR),, Informatika., Bandung, 2008. 